\title{
Chest Pain and Single Troponin
}

\section{Göğüs Ağrısı ve Tek Troponin}

\author{
Süha Serin', @Bahadır Çağlar' \\ 'Balikesir University School of Medicine Department of Emergency Medicine, Balikesir, Turkey
}

\begin{abstract}
Aim: It is important to exclude the diagnosis of acute coronary syndrome quickly and accurately. This study aims to exclude the diagnosis of acute myocardial infarction (AMI) with a single troponin value in patients with appropriate clinical evaluation and electrocardiography (ECG)
\end{abstract}

Materials and Methods: Among the patients who were followed up with a pre-diagnosis of AMI and for whom a HEART score was calculated, patients whose high sensitive troponin I result was found below the limit of detection (LoD) value and who were discharged is included in study. All patients were contacted on the 30th day of discharge. The status of "major adverse cardiac events" (MACE-30) in the last 30 days was questioned.

Results: The HEART score of 122 patients (73.1\%) in the study was found to be at low risk while $45(26.9 \%)$ as moderate. MACE-30 developed in only 5 patients (3\%). Of the 5 patients who developed Mace; The HEART score of $3(60 \%)$ was determined as 5, whereas the heart score of $2(40 \%)$ was 6. $p<0.001$. It was observed that no mace was detected in any patient with a low risk HEART score $(p<0.001)$. The cut off value for the heart score was found to be $\leq 4(p<0,001)$ while the cut off value for age was found to be $\leq 69(p<0,001)$.

Conclusion: We think that patients presenting to the emergency with chest pain, a troponin value below LoD and a low HEART score can be discharged from the emergency department with a single troponin.

Keywords: Emergency service, angina, acute coronary syndrome, troponin
Öz

Amaç: Akut koroner sendrom tanısını hızlı ve doğru şekilde dışlamak önemlidir. Çalışmanın amacı, klinik değerlendirme ve elektrokardiyogarfisi (EKG) uygun hastalarda, tek troponin değeri ile akut miyokard enfarktus (AMI) tanısını dışlamaktır.

Gereç ve Yöntem: Acil serviste AMI ön tanısı ile izlenen ve HEART score hesaplanan hastalar arasından; high sensitive troponin I sonucu limit of detection (LoD) değeri altında saptanan ve taburcu edilen hastalar çalışmaya alındı. Tüm hastalar taburculuğun 30. gününde telefon ile arandı. Son 30 gün içinde "major adverse cardiac events" (MACE-30) durumları sorgulandı.

Bulgular: Çalışmadaki 122 hastanın (73.1\%) HEART score low risk, 45 hastanın (26.9\%) HEART score moderate risk olarak bulundu. MACE-30 sadece 5 hastada (3\%) gelişmiştir. Mace gelişen toplam 5 hastadan; 3 ünün (60\%) HEART score 5, 2 sinin (40\%) heart skoru 6 olarak saptandı. p<0,001. HEART score low risk olan hiçbir hastada mace saptanmadığı görüldü. $(p<0,001)$. Heart skoruna yönelik cut off değeri $\leq 4$ olarak bulundu. $(p<0,001)$. Yaş için cut off değeri $\leq 69$ bulunmuştur. $(p<0,001)$.

Sonuç: Göğüs ağrısı ile acil servise başvuran, troponin LoD değerinin altında olan ve düşük HEART skorlu hastaların acil servisten tek troponin ile taburcu edilebileceğini düşünüyoruz.

Anahtar Sözcükler: Acil servis, anjina, akut koroner sendrom, troponin 


\section{INTRODUCTION}

Millions of people present to emergency departments with chest pain complaints worldwide. ${ }^{[1]}$ Acute coronary syndrome (ACS), one of the main and most important causes of chest pain, is a definition that covers the situations in which the myocardial cell is damaged reversibly or irreversibly. One of the main causes of this damage is the inability to supply the oxygen needs to the myocardial cell. The duration of oxygen deprivation of myocardial cells affects the extent of myocardial damage, and the extent of the damage affects the patient's mortality and morbidity. The diagnosis of ACS, which consists of unstable angina pectoris, ST elevation myocardial infarction (STEMI) and non-ST elevation myocardial infarction (NSTEMI), is made with the patient's history, electrocardiography (ECG) findings, and cardiac biomarkers. Currently, highly sensitive troponins are used as cardiac biomarkers. The use of new generation troponins allows us to measure lower troponin concentrations, making it easier to diagnose and exclude ACS in the early period.

$80-90 \%$ of the patients who present to the emergency department with chest pain are diagnosed other than ACS. [2-4] Therefore, it is also important to exclude the diagnosis of ACS in the emergency department quickly and accurately. In recent years, strategies have been developed to identify patients without AMI (acute myocardial infarction) and to exclude AMI diagnosis more rapidly. ${ }^{[2-10]}$ One of these strategies is to demonstrate that AMI can be excluded with a single troponin if the troponin value at presentation is below the limit of detection (LoD).

Details of the patient history and laboratory errors are among the obstacles for physicians to exclude the diagnosis of AMI with a single troponin value. ${ }^{[8,11]}$ Using clinical evaluation and ECG in addition to troponin to exclude the diagnosis of AMI will make patient management safer. This study aims to exclude the diagnosis of AMI with a single troponin value in patients with appropriate clinical evaluation and ECG.

\section{MATERIALS AND METHODS}

The study was initiated after obtaining the permission of Balıkesir University Clinical Research Ethics Committee, dated 08.04.2020 and numbered 2020/47. Patients who were admitted to Balıkesir University Hospital emergency service between October 2019 and July 2020 were examined. Among the patients followed up in the emergency department with a pre-diagnosis of AMl; 192 patients with no STEMl findings on ECG, who had a value below LoD as a result of high sensitive troponin I (hsTnl) at the time of admission and who were discharged from the emergency room by the primary physician after emergency room follow-up were included in the study. The HEART (history, ECG, age, risk factors and troponin) scores of the patients were calculated, and according to scores, 0-3 points were assigned as "low risk", 4-6 points as "moderate risk" and 7-10 points as "high risk", which is consistent with the literature (Table 1). ${ }^{[2]}$
Table 1. Composition of the HEART score 2

\begin{tabular}{|c|c|c|}
\hline HEART Score & Score & \\
\hline \multirow{3}{*}{ History } & Highly suspicious & 2 \\
\hline & Moderately suspicious & 1 \\
\hline & Slightly suspicious & 0 \\
\hline \multirow{3}{*}{ ECG } & Significant ST depression & 2 \\
\hline & Nonspecific repolarisation disturbance & 1 \\
\hline & Normal & 0 \\
\hline \multirow{3}{*}{ Age } & $\leq 65$ year & 2 \\
\hline & 45-65 year & 1 \\
\hline & $<45$ year & 0 \\
\hline \multirow{3}{*}{ Risk factors } & $\geq 3$ risk factors or history of atherosclerotic disease & 2 \\
\hline & 1 or 2 risk factors & 1 \\
\hline & No risk factors known & 0 \\
\hline \multirow{3}{*}{ Troponin } & $>2 x$ normal limit & 2 \\
\hline & $1-2 x$ normal limit & 1 \\
\hline & $\leq$ normal limit & 0 \\
\hline
\end{tabular}

Blood samples for hsTnl at the time of arrival were collected by gel tube (BD Vacutainer SST II). Blood samples were studied in the hospital central laboratory using Unicel DXI 800 and Beckman Coulter device with ACCESS hsTnl (RefB52699) kit and chemiluminescent immunoassay two step immunoenzymatic (sandwich) method. The LoD value of the kit is $<2.3 \mathrm{ng} /$ l. All patients were called on the 30th day of discharge. The status of "major adverse cardiac events" (MACE-30) in the last 30 days was questioned.

Statistical Method: SPSS 26.0 (IBM Corporation, Armonk, New York, United States) program was used in the analysis of variables. The normality distribution of univariate data was evaluated using the Shapiro-Wilk francia test. Mann-Whitney $U$ test as well as Monte Carlo results were used to compare two independent groups according to quantitative data. In the comparison of categorical variables, the Fisher Exact test and the Fisher-Freeman-Holton test results were tested with the MonteCarloSimulation technique, and the column proportions were compared and expressed according to the BenjaminiHochberg corrected $p$-value results. Relative risk values were calculated with $95 \%$ confidence intervals to examine the rate of development of the MACE-30 (or occurrence) of those with a risk factor relative to those without. The sensitivity and specificity ratios for the relationship between the classification separated by the cut-off value calculated according to the variables of the groups and the actual classification were examined and expressed by ROC (Receiver Operating Curve) curve analysis. Quantitative variables were expressed as mean \pm SD (Standard Deviation) and Median (Minimum / Maximum) in tables, while categorical variables were shown as $\mathrm{n}(\%)$. Variables were analyzed at a $95 \%$ confidence level and a $p$ value of less than 0.05 was considered significant. 


\section{RESULTS}

Evaluations were made on 167 patients (86.9\%) who were contacted by phone on the 30th day of discharge. Patients who could not be reached were checked through the national death reporting system to exclude mortality risk, and no patients who died were found.

$52.1 \%$ of 167 patients in the study were male (n: 87$)$ and the mean age was $42.54 \pm 13.72$ (min: 19 - max: 83). The HEART score of 122 patients $(73.1 \%$ ) was found to be low risk and 45 patients $(26.9 \%)$ as moderate risk. No patient with a high risk score was found. The HEART score mean value of the patients was found to be $2.44 \pm 1.58$ (min: 0 - max: 6) (Table 2).

MACE-30 developed in only 5 patients (3\%). No exitus was found in those patients. Of the 5 patients who developed Mace, the HEART score of $3(60 \%)$ was determined as 5, and the heart score of $2(40 \%)$ was $6 . p<0.001$. It was observed that no mace was detected in any patient with a HEART score as low risk $(p<0.001)$. The cut off value for the heart score was found to be $\leq 4 .<0,001$ SEN \%100 SPE 95,1\% AUC (SE): 0,976 $(0,011)$. The mean age of 5 patients who developed MACE30 was 71 (min: 53 - max: 83), and the mean age of patients without MACE-30 was 39.5 (min: 19 - max: 73). The cut off value for age was found to be $\leq 69$ ( $p<0,001$ SEN $80 \%$ SPE $96,9 \%$ AUC (SE): 0,944 (0,043) (Table 3, Figure 1,2).
Table 2. Distribution of patients according to age, sex, heart score and MACE-30

\begin{tabular}{|c|c|c|}
\hline & Mean \pm SD. & Min- Q1- Q2- Q3- Max \\
\hline \multirow[t]{2}{*}{ Age } & $42,54 \pm 13,72$ & $19-34-40-53$ \\
\hline & $\mathbf{n}$ & $\%$ \\
\hline \multicolumn{3}{|l|}{ Sex } \\
\hline Female & 80 & $47,9 \%$ \\
\hline \multirow[t]{2}{*}{ Male } & 87 & $52,1 \%$ \\
\hline & Mean \pm SD. & Min- Q1- Q2- Q3- Max \\
\hline \multirow[t]{2}{*}{ Heart Score } & $2,44 \pm 1,58$ & $0-1-3-4-6$ \\
\hline & $\mathbf{n}$ & $\%$ \\
\hline \multicolumn{3}{|l|}{ Heart Score } \\
\hline 0 & 26 & $15,6 \%$ \\
\hline 1 & 22 & $13,2 \%$ \\
\hline 2 & 34 & $20,4 \%$ \\
\hline 3 & 40 & $24,0 \%$ \\
\hline 4 & 32 & $19,2 \%$ \\
\hline 5 & 8 & $4,8 \%$ \\
\hline 6 & 5 & $3,0 \%$ \\
\hline \multicolumn{3}{|l|}{ Heart Score } \\
\hline low risk & 122 & $73,1 \%$ \\
\hline moderate risk & 45 & $26,9 \%$ \\
\hline \multicolumn{3}{|l|}{ MACE-30 days } \\
\hline absent & 162 & $97,0 \%$ \\
\hline present & 5 & $3,0 \%$ \\
\hline
\end{tabular}

Table 3. Relationship of age, sex and heart score to MACE-30

\begin{tabular}{|c|c|c|c|}
\hline & \multicolumn{2}{|c|}{ MACE-30 days } & \multirow{2}{*}{$\mathbf{P}$} \\
\hline & $\begin{array}{c}\text { absent }(n=162) \\
n(\%)\end{array}$ & $\begin{array}{c}\text { present }(n=5) \\
n(\%)\end{array}$ & \\
\hline Sex & & & $0,671 \mathrm{fe}$ \\
\hline Female & $77(47,5)$ & $3(60,0)$ & \\
\hline \multirow[t]{2}{*}{ Male } & $85(52,5)$ & $2(40,0)$ & \\
\hline & Median (Min / Max) & Median (Min / Max) & \\
\hline \multirow[t]{2}{*}{ Age } & $39,5(19 / 73)$ & $71(53$ / 83) & $<0,001 \mathrm{u}$ \\
\hline & $\mathrm{n}(\%)$ & $\mathrm{n}(\%)$ & \\
\hline Age & & & $<0,001 \mathrm{rc}$ \\
\hline$\leq 69$ & $157(96,9) \mathrm{sp}$ & $1(20,0)$ & AUC (SE): $0,944(0,043)$ \\
\hline \multirow[t]{2}{*}{$>69$} & $5(3,1)$ & $4(80,0)$ ss & $70,22(8,72-565,4) \mathrm{rr}$ \\
\hline & Median (Min / Max) & Median (Min / Max) & \\
\hline \multirow[t]{2}{*}{ Heart Score } & $2(0 / 6)$ & $5(5 / 6)$ & $<0,001 \mathrm{u}$ \\
\hline & $\mathrm{n}(\%)$ & $\mathrm{n}(\%)$ & \\
\hline Heart Score & & & $<0,001 \mathrm{ff}$ \\
\hline 0 & $26(16,0) B$ & $0(0,0)$ & \\
\hline 1 & $22(13,6) \mathrm{B}$ & $0(0,0)$ & \\
\hline 2 & $34(21,0) \mathrm{B}$ & $0(0,0)$ & \\
\hline 3 & $40(24,7) \mathrm{B}$ & $0(0,0)$ & \\
\hline 4 & $32(19,8) B$ & $0(0,0)$ & \\
\hline 5 & $5(3,1)$ & $3(60,0) A$ & \\
\hline 6 & $3(1,9)$ & $2(40,0) \mathrm{A}$ & \\
\hline Heart Score & & & $<0,001 \mathrm{rc}$ \\
\hline$\leq 4$ & $154(95,1) \mathrm{sp}$ & $0(0,0)$ & AUC (SE): $0,976(0,011)$ \\
\hline$>4$ & $8(4,9)$ & $5(100,0) \mathrm{ss}$ & $124,9(7,3-2144,8) \mathrm{rr}$ \\
\hline Heart Score & & & $0,001 \mathrm{fe}$ \\
\hline low risk & $122(75,3) \mathrm{B}$ & $0(0,0)$ & $29,4(1,7-521,5) r r$ \\
\hline moderate risk & $40(24,7)$ & $5(100,0) A$ & \\
\hline
\end{tabular}




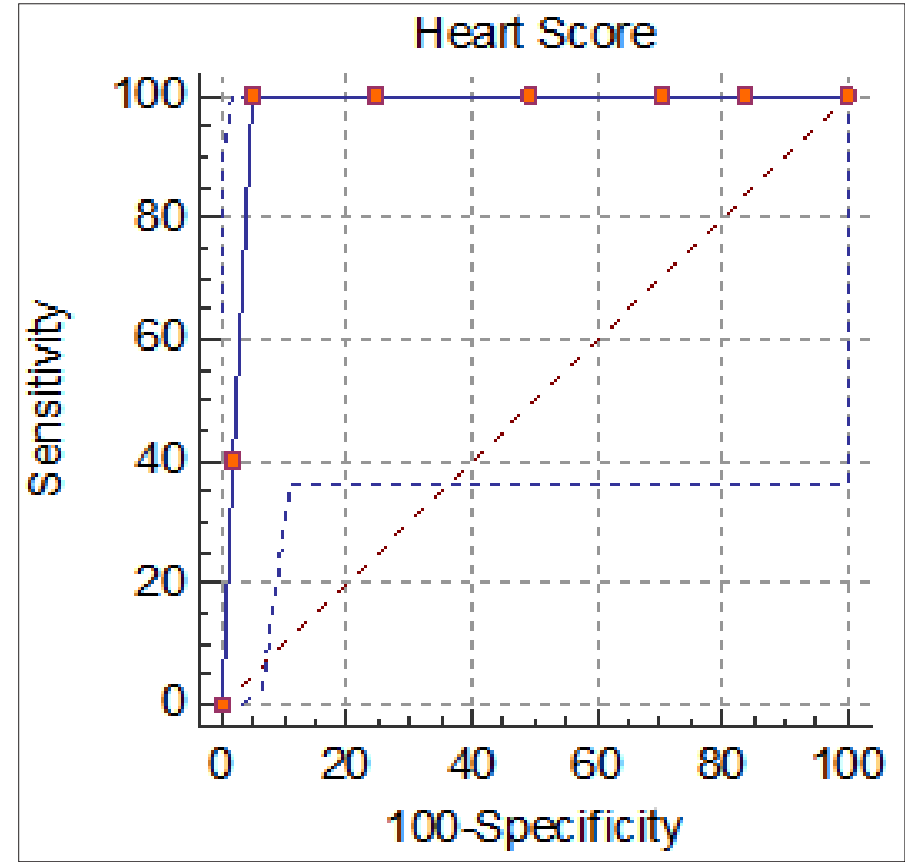

Figure 1. Roc analysis of the sensitivity and specificity ratios for the heart score by the cut-off value

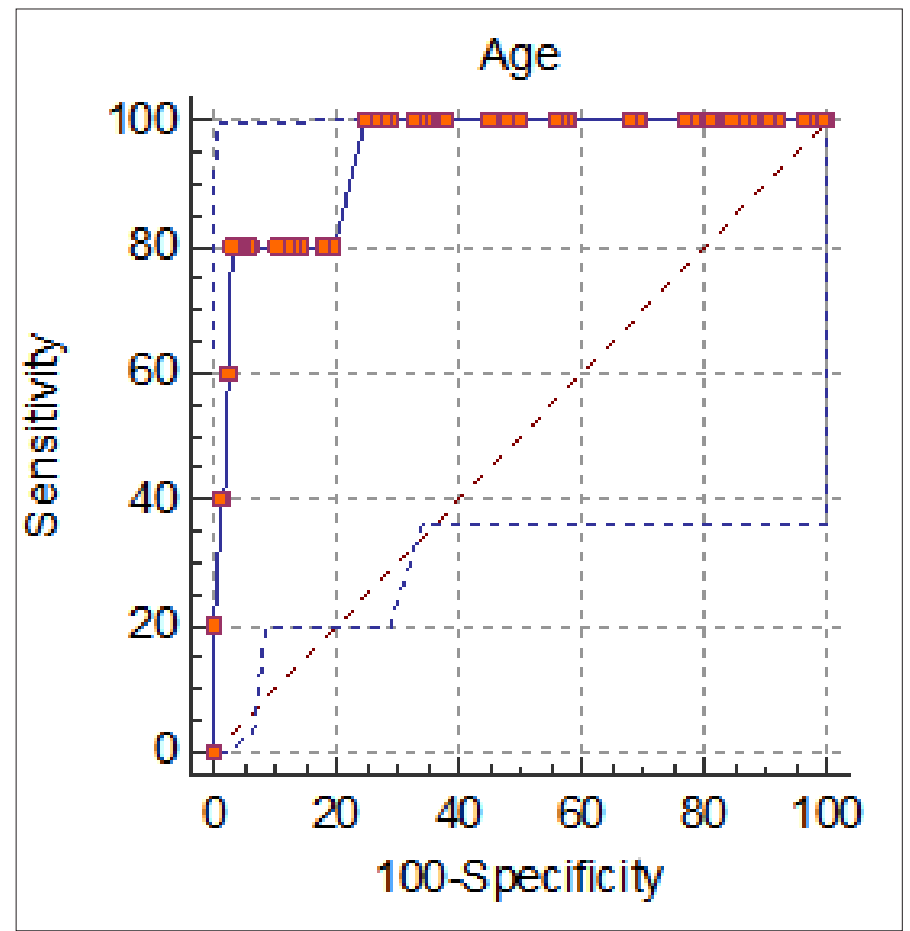

Figure 2. Roc analysis of the sensitivity and specificity ratios for the age by the cut-off value

\section{DISCUSSION}

Emergency services meet an increasing workload in our country as in worldwide and have an important place in health systems. For this reason, it is very important to use emergency services effectively. Patients who are followed up in emergency services with a pre-diagnosis of AMI have an important share. According to current guidelines, patients with chest pain are followed up with troponin every 3 hours. [12] Testing control troponin from a patient will extend the patient's stay in the emergency room from approximately 1 hour to 4 hours, if we also calculate the laboratory time of the blood sample.

In our study, we aimed to find out whether eligible patients can be discharged from the emergency department with a single troponin by examining the relationship between HEART score and MACE-30 in patients with troponin values below LoD. In our study, the rate of MACE-30 was found to be $2.9 \%$ (5 patients) in patients who were followed up with a pre-diagnosis of AMI, whose troponin value was below LoD, and who were discharged from the emergency department by the primary physician. The HEART score of the patients who developed MACE-30 was found to be 5 and above, and 4 of the 5 patients were $>69$ years old.

In the literature, there are studies showing that if the troponin result is below the limit of blank (LoB) or LoD, patients can be discharged with a single troponin, thus reducing the hospital stay and cost. ${ }^{[6-10,13-17]}$ In the study conducted by Bandstein et al on 14636 patients, it was stated that patients with troponin values below the LoD value and without signs of ischemia in their ECG can be safely discharged from the emergency department. ${ }^{[8]}$

However, an increase in troponin may not be detected in the first hours after the infarction begins. ${ }^{[12]}$ Therefore, troponin results should not be merely interpreted. ${ }^{[18]}$ For this reason, we combined troponin value with heart risk score in this study as we think that the HEART score is easily applicable in emergency services. When calculating the HEART score, a score between 0 and 10 points is created based on the patient's history, age, risk factors, ECG findings, and troponin result. ${ }^{[2]}$ In HEART scoring; the most critical age group is $\geq 65$ and 0-3 point range is stated as low risk. ${ }^{[19,20]}$ In our study, we found the 0-4 score range and age $<69$ as low risk. However, when we consider the limited number of patients, we observe that we have reached parallel results with the HEART scoring system.

In addition, thanks to the developing technology and widespread network, we think that informatics in healthcare will advance, thus these scores will be calculated automatically in digital environment by considering the patient's history in the following years, which may help physicians in the management of patients with chest pain with decision support systems (DSS). ${ }^{[1]}$

Limitations: The main limitations are that our study was conducted in a single center, $13.1 \%$ of the patients could not be reached, and the total number of patients was limited. The limited number of our patients is one of the main limitations. Multicenter studies with larger numbers of patients are needed to make cut off values more indicative. In addition, not focusing the diagnosis of discharge is one of the deficiencies of our study. 


\section{CONCLUSION}

Acute coronary syndrome, which is the leading cause of death in the world, is diagnosed in the emergency department. In our study, AMI or MACE-30 did not develop within 30 days in patients with troponin levels below LoD and low HEART scores. We think that patients who meet these criteria can be discharged from the emergency department with a single troponin.

\section{ETHICAL DECLARATIONS}

Ethics Comittee Approval: This study was conducted with the Balikesir University Clinical Research Ethic Committee with decision no. 2020/47.

Informed Consent: Written informed consent was obtained from all participants who participated in this study.

Status of Peer-review: Externally peer-reviewed.

Conflict of Interest Statement: The authors have no conflicts of interest to declare.

Financial Disclosure: The authors declared that this study has received no financial support.

\section{REFERENCES}

1. Datlow Mitchell D. et al. Troponin limit of detection plus cardiac risk stratification scores to rule out acute myocardial infarction and 30day major adverse cardiac events in ED patients. Critical pathways in cardiology 2017;16.4:142.

2. Six AJ, Backus BE, Kelder JC. Chest pain in the emergency room:value of the HEART score. Neth Heart J 2008;16:191-6.

3. Hess EP, Brison RJ, Perry JJ, Calder LA, Thiruganasambandamoorthy V, Agarwal D et al. Development of a clinical prediction rule for 30-day cardiac events in emergency department patients with chest pain and possible acute coronary syndrome. Ann Emerg Med 2012;59:115-25.

4. Than M, Flaws D, Sanders S, Doust J, Glasziou P, Kline J et al. Development and validation of the Emergency Department Assessment of Chest Pain Score and $2 \mathrm{~h}$ accelerated diagnostic protocol. Emerg Med Australas 2014;26:34-44.

5. Pickering John W. et al. Rapid rule-out of acute myocardial infarction with a single high-sensitivity cardiac troponin $\mathrm{T}$ measurement below the limit of detection:a collaborative meta-analysis. Annals of internal medicine 2017;166.10:715-724.

6. Body, Richard, and Charles Reynard. "One shot to rule out:does the limit of detection of a high-sensitivity troponin assay hit the mark?." (2017):21-23.

7. Body R, Carley S, McDowell G, Jaffe AS, France M, Cruickshank Ket al. Rapid exclusion of acute myocardial infarction in patients with undetectable troponin using a highsensitivity assay. J Am Coll Cardiol 2011;58:1332-9.

8. Bandstein N, Ljung R, Johansson M, Holzmann MJ. Undetectable high sensitivity troponin $\mathrm{T}$ level in the Emergency Department and risk of myocardial infarction. J Am Coll Cardiol 2014;63:2569 -78.

9. Body R, Burrows G, Carley S, Cullen L, Than M, Jaffe AS et al. Highsensitivity cardiac troponin t concentrations below the limit of detection to exclude acute myocardial infarction:a prospective evaluation. Clin Chem 2015;61:983-9.

10. Body R, Carley SD, Burrows G, Mackway-Jones K. The Manchester Acute Coronary Syndromes (MACS) decision rule to reduce unnecessary admissions for cardiac chest pain:derivation and external validation. Acad Emerg Med 2012;19:744.

11. Cullen $L$, Than M, Peacock WF. Undetectable hs-cTnT in the emergency department and risk of myocardial infarction. J Am Coll Cardiol 2014;64:632-3. [PMID:25104539] doi:10.1016/j.jacc.2014.04.061
12. Kristian Thygesen, Joseph S Alpert, Allan S Jaffe, Bernard R Chaitman, Jeroen J Bax, David A Morrow ET AL. ESC Scientific Document Group, Fourth universal definition of myocardial infarction (2018). European Heart Journal 2019;40(3):237-269.

13. Falvo T, Grove L, Stachura R et al. The opportunity loss of boarding admitted patients in the emergency department. Acad Emerg Med 2007;14:332-7.

14. Gomez MA, Anderson JL, Karagounis LA, Muhlestein JB, Mooers FB. An emergency department-based protocol for rapidly ruling out myocardial ischemia reduces hospital time and expense:results of a randomized study (ROMIO). J Am Coll Cardiol 1996;28:25-33.

15. Shortt C, Ma J, Clayton N, Sherbino J, Whitlock R, Pare G et al. Rule-in and rule-out of myocardial infarction using cardiac troponin and glycemic biomarkers in patients with symptoms suggestive of acute coronary syndrome. Clin Chem 2017;63:403-14.

16. Shah ASV, Anand A, SandovalY, Lee KK, Smith SW, Adamson PD et al. Highsensitivity cardiac troponin I at presentation in patients with suspected acute coronary syndrome:a cohort study. Lancet 2015;386:2481-8.

17. Neumann JT, Sorensen NA, Ojeda F, Schwemer T, Lehmacher J, Gonner $S$ et al. Immediate rule-out of acute myocardial infarction using electrocardiogram and baseline high-sensitivity troponin I. Clin Chem 2017;63:394 - 402 .

18. Anderson JL, Adams CD, Antman EM et al. 2012 ACCF/AHA focused update incorporated into the ACCF/AHA 2007 guidelines for the management of patients with unstable angina/non-ST-elevation myocardial infarction:a report of the American College of Cardiology Foundation/American Heart Association Task Force on Practice Guidelines. J Am Coll Cardiol 2013;61:e179-347.

19. Backus BE, Six AJ, Kelder JC et al. Chest pain in the emergency room:a multicenter validation of the HEART Score. Crit Pathw Cardiol 2010;9(3):164-169.

20. Backus BE, Six AJ, Kelder JC et al. A prospective validation of the HEART score for chest pain patients at the emergency department. Int J Cardiol 2013;168(3):2153-2158. 